\title{
DESAIN KONSEPTUAL GROUND-BASED GENERATOR (GBG) OTOMATIS DAN KONSEP OPERASIONAL BERBASIS WIRELESS SENSOR NETWORK (WSN)
}

\author{
Purwadi ${ }^{1}$, T.H. Seto ${ }^{2}$
}

\begin{abstract}
Intisari
Dilatarbelakangi oleh beberapa permasalahan operasional Teknologi Modifikasi Cuaca (TMC) dengan wahana pesawat terbang dan juga permintaan TMC yang semakin meningkat, maka dilakukan pengembangan teknologi Ground-Based Generator berupa desain konseptual Ground-Based Generator (GBG) otomatis dan konsep operasional berbasis wireless sensor network (WSN). Dari kajian teori, teknologi GBG efektif diterapkan dilereng pegunungan, sehingga konsep pengembangan teknologi ini dimaksudkan untuk operasional TMC waduk PLTA di Indonesia yang sebagian besar dikelilingi oleh daerah aliran sungai (DAS) berupa pegunungan. Di dalam tulisan ini dijelaskan 4 topografi waduk PLTA yang telah lama menggunakan jasa TMC yaitu DAS Riamkanan, DAS Larona, DAS Koto Panjang, dan DAS Singkarak. Data topografi yang menunjukkan kelayakan suatu DAS dapat diterapkan GBG diperoleh dari Digital Elevation Model (DEM) dan ditampilkan dengan software Global Maper. Selanjutnya, rancangan GBG otomatis di ilustrasikan dalam sketsa gambar. GBG otomatis memiliki fitur; autoloading flare, rak penyimpanan flare, solar panel, dan dikontrol dengan mikroprosesor. Dengan menerapkan konsep WSN, pengoperasian GBG dapat dilakukan secara terpusat untuk beberapa DAS sekaligus, sehingga kegiatan TMC mejadi lebih efektif dan efisien.
\end{abstract}

\begin{abstract}
Motivated by some operational problems of Weather Modification Technology (TMC) with airplane medium and also increasing the demand of TMC, then the development of Ground-Based Generator technology in the form of conceptual design of automatic Ground-Based Generator (GBG) and operational concepts based wireless sensor network (WSN) is done. From the study of theory, GBG effectively applied on mountain slope, so the concept of development of this technology is intended for TMC operation in hydroelectric (PLTA) dam in Indonesia that were mostly surrounded by watersheds (DAS) in the form of mountains. This paper describe four hydroelectric dams topography which has long used the TMC service (Riam Kanan DAS, DAS Larona, DAS Koto Panjang, and DAS Singkarak). The topographic data that indicate the feasibility of applied GBG in a watershed is obtained from the Digital Elevation Model (DEM) and displayed with Global Mapper software. Furthermore, the design of automatic GBG is illustrated in sketch drawings. The designed GBG has automatic features; autoloading flares, flare storage racks, solar panels, and controlled by a microprocessor. By applying the concept of WSN, GBG operation can be performed centrally for multiple DAS at once, so that the activities of TMC becoming more effective and efficient.
\end{abstract}

Kata kunci: Teknologi Modifikasi Cuaca, Wireless Sensor Network, Ground-based Generator, PLTA.

\section{PENDAHULUAN}

Saat ini, Teknologi Modifikasi Cuaca (TMC) merupakan teknologi yang sedang menjadi sorotan di Indonesia dalam mengatasi berbagai bencana alam seperti banjir DKI Jakarta, penanggulangan kebakaran hutan dan lahan, dan juga bencana kekeringan. Selain untuk penanggulangan bencana, permintaan TMC juga bertujuan untuk pengisian waduk pada pembangkit listrik tenaga air (PLTA) dan juga irigasi. Dari data UPT-Hujan Buatan BPPT, permintaan akan teknologi ini menunjukkan tren yang semakin meningkat. Dari tahun 1977 hingga Juli 2014 permintaan TMC untuk PLTA menunjukkan angka yang cukup tinggi dan konsisten dari tahun ke tahun. Sehingga PLTA merupakan salah satu pasar potensial TMC. Unit Pelaksana Teknis Hujan Buatan (UPT- Hujan Buatan) BPPT merupakan satu- 
satunya institusi yang menyediakan jasa pelayanan TMC di Indonesia. Dengan semakin meluasnya pemanfaatan TMC untuk penanggulangan becana kebakaran hutan dan lahan serta penanggulangan bencana banjir, UPTHujan Buatan BPPT semakin kewalahan memenuhi semua permintaan TMC yang ada saat ini. Peningkatan jumlah permintaan pasar ini tidak diikuti oleh bertambahnya jumlah armada pesawat sebagai wahana utama kegiatan TMC di Indonesia saat ini. Sedangkan, alternatif pengganti wahana pesawat ini masih dalam proses pengembangan dan belum menemui hasil yang maksimal.

Motivasi lain untuk mencari alternatif pengganti wahana pesawat terbang untuk melakukan TMC dikarenakan biaya peswat yang cukup tinggi walaupun air hasil TMC dengan pesawat masih ekonomis. Dari gambar 2, terlihat bahwa penyemaian awan dengan pesawat melebihi harga bahan semai [1]. Sedangkan biaya penyemaian dari darat yang berupa Ground Base Generator dan Ground Particle Generator (GPG) yang beroperasi 24 jam hanya menyerap $2 \%$ dari total biaya operasi TMC.

Ground Base Generator (GBG) dengan bahan semai flare sebagai alternatif wahana penyemaian awan hanya cocok diaplikasikan di lereng gunung untuk menyemai awan-awan orografik, dengan memanfaatkan angin gunung untuk menghantarkan bahan semai ke awan. Secara umum, waduk PLTA di Indonesia sebagai market potensial TMC dikelilingi oleh bukit maupun pegunungan yang memungkinkan banyak tumbuh awan-awan orografik. Sehingga teknologi GBG dapat diterapkan pada operasi pengisian waduk PLTA yang mana banyak dikelilingi oleh bukit maupun pegunungan.

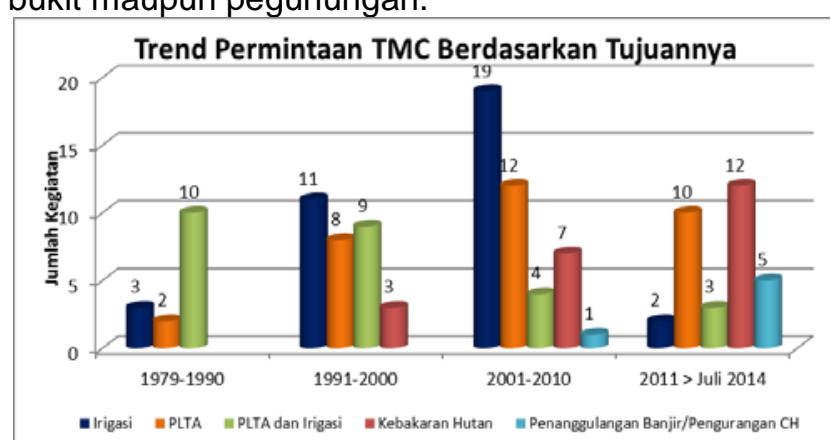

(a)

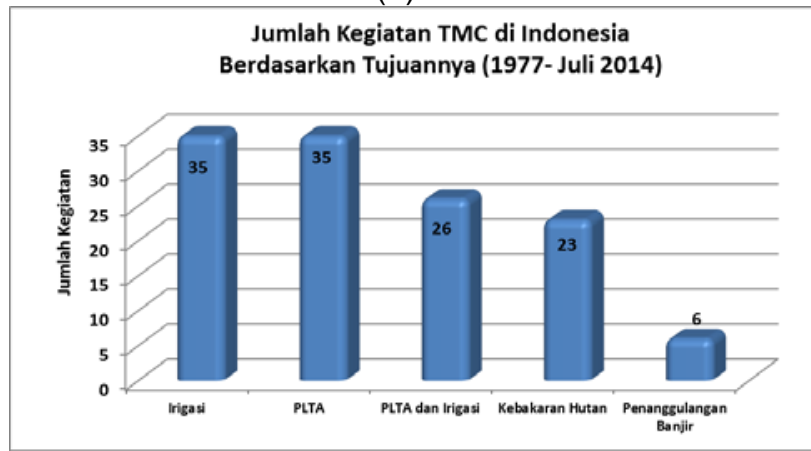

(b)

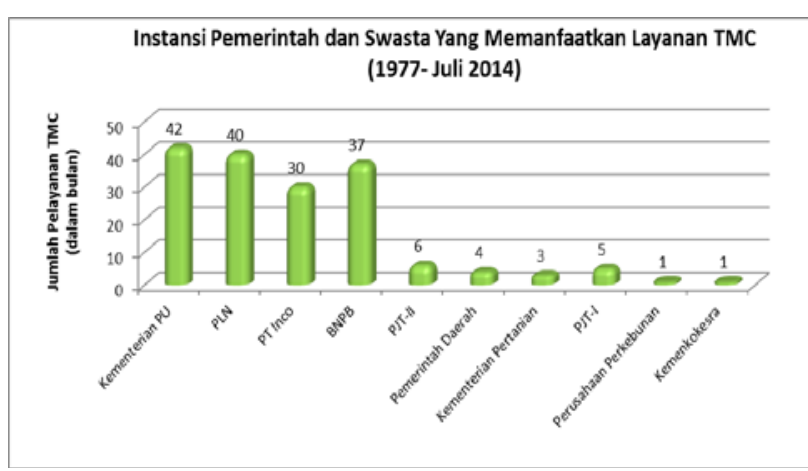

(c)

Gambar 1. (a) Grafik jumlah permintaan TMC dari tahun 1977- Juli 2014 (b) Grafik Trend permintaan

TMC (c) Instansi pemerintah dan swasta yang memakai layanan TMC.

Menara Ground Base Generator (GBG) saat ini sudah dikembangkan oleh UPT-Hujan Buatan BPPT sebagai alternatif pengganti pesawat terbang untuk penyemaian memanfaatkan angin orografik. Menara GBG yang dikembangkan BPPT di Citeko Bogor memiliki tinggi 50 meter dan dipasang dilereng gunung untuk mendekati dasar awan. Teknologi GBG yang sudah ada saat ini juga sudah mendapatkan sentuhan teknologi berupa pengiriman kode SMS untuk memicu pembakaran flare, namun dalam hal pemasangan dan menaikkan flare ke atas menara masih dilakukan oleh operator secara langsung. Sehingga GBG yang dikembangkan saat ini belum efektif karena GBG yang dipasang di lereng gunung yang terpencil masih membutuhkan operator secara langsung untuk pengoperasiannya. Oleh karena itu, teknologi ini masih perlu terus dikembangan lebih lanjut kearah otomatis dan sekaligus bisa dikontrol jarak jauh sehingga pengoperasian GPG ditempat terpencil menjadi efektif dan aman.

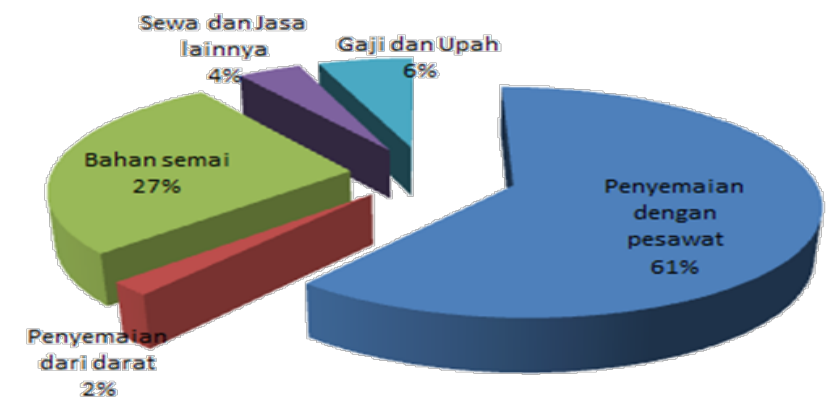

Gambar 2. Komponen biaya TMC penanggulangan Banjir Jakarta.

\section{DASAR TEORI}

\subsection{Awan Orografik}

Sebuah parcel udara lembab dipaksa naik karena adanya halangan berupa gunung hingga mencapai titik kondensasi akan menghasilkan awan orografik. Secara umum, curah hujan tahunan dataran tinggi pada umumnya lebih tinggi 
dibanding dataran rendah dan sekitarnya, terutama pada lereng yang menghadap arah datangnya angin[2-5].

Pengaruh dataran tinggi pada peningkatan curah hujan terutama adalah memberikan dorongan (paksaan) udara untuk naik. Pengaruh lain yang tidak langsung adalah :

a) Menghasilkan turbulensi alamiah yang kuat baik mekanik maupun konvektif karena melewati permukaan yang kasar.

b) Merupakan penghalang dan memperlambat gerakan depresi (badai siklon).

c) Menimbulkan konvergensi pada udara horisontal karenan melewati lembah yang menyerupai cerobong.

d) Memicu udara naik sebagai awal ketidakstabilan.

Dorongan naik oleh pegunungan maupun dataran tinggi membawa udara sampai ke aras kondensasi. Setelah itu penambahan panas hasil kondensasi membuat udara menjadi tidak stabil dan terus naik.

\subsection{Teknologi Modifikasi Cuaca}

Penyemaian awan (clouds seeding) adalah Teknik untuk memodifikasi cuaca dengan menebar bahan semai ke dalam awan baik dengan media pesawat terbang maupun dari darat untuk mendorong pertumbuhan droplet menjadi lebih cepat dan banyak, sehingga intensitas hujan yang turun semakin tinggi. Bahan semai yang ditebar dalam awan akan mempengaruhi proses mikrofisik dari awan. Sistem ini sebetulnya menirukan proses yang terjadi secara alami dimana proses terbentuknya droplet dan presipitasi memerlukan inti kondensasi yang biasa disebut Cloud Condensation Nuklei (CCN). Inti kondensasi adalah partikel padat atau cair yang dapat berupa debu, asap, belerang dioksida, garam laut $(\mathrm{NaCl})$ atau benda mikroskopik lainnya yang bersifat higroskopis, dengan ukuran 0,001 10 mikrometer. Banyaknya inti kondensasi menentukan kecepatan terbantuknya tetes-tetes air (droplet). Proses dimana droplet dari fasa uap terbentuk pada inti kondensasi disebut pengintian heterogen. Tanpa adanya inti kondensasi pembentukan droplet dilingkungan murni memerlukan kondisi yang sangat jenuh (supersaturation). Kondisi ini sisebut pengintian homogen. Pengintian homogen sulit terjadi dilingkungan alami karena kondisi ini hanya akan terjadi pada suhu dibawah $-40{ }^{\circ} \mathrm{C}$. Akan tetapi dengan adanya inti kondensasi , maka pembentukan droplet dapat terjadi hanya beberapa derajat dibawah $0^{\circ} \mathrm{C}[2-5]$.

\subsection{Ground - Based Particle Generator}

Salah satu teknik TMC yang dikembangkan didunia dan juga di Indonesia adalah Ground Base Generator (GBG). GBG banyak digunakan untuk penyemaian awan di lereng gunung dengan memanfaatkan angin orografik untuk menghantarkan bahan semai ke awan. Gambar 4 menunjukka proses penyemaian awan dengan GBG di lereng gunung.

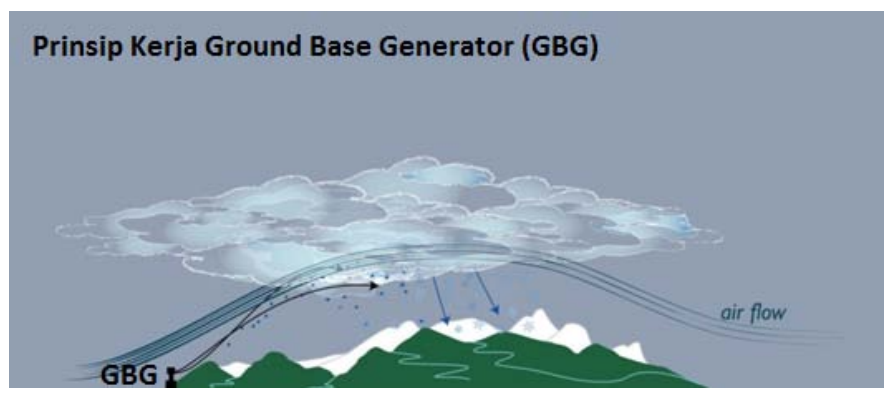

Gambar 3. Prinsip Kerja Ground Based Generator

GBG merupakan alat didarat yang berfungsi untuk menghasilkan partikel bahan semai. Alat ini dapat berupa tungku/cerobong pembakaran maupun berbentuk flare. Flare merupakan bahan semai yang cara kerjanya dibakar untuk menghasilkan partikel yang serupa dengan asap. Flare yang diciptakan oleh UPTHujan Buatan mampu menghasilkan partikel berukuran berukuran 1.1 - 9 mikron [6]. Flare sudah banyak digunakan sebagai bahan penyemaian awan baik melalui wahana pesawat maupun penyemaian dari darat berupa pohon flare, ditunjukkan oleh gambar 5 dan 6 .

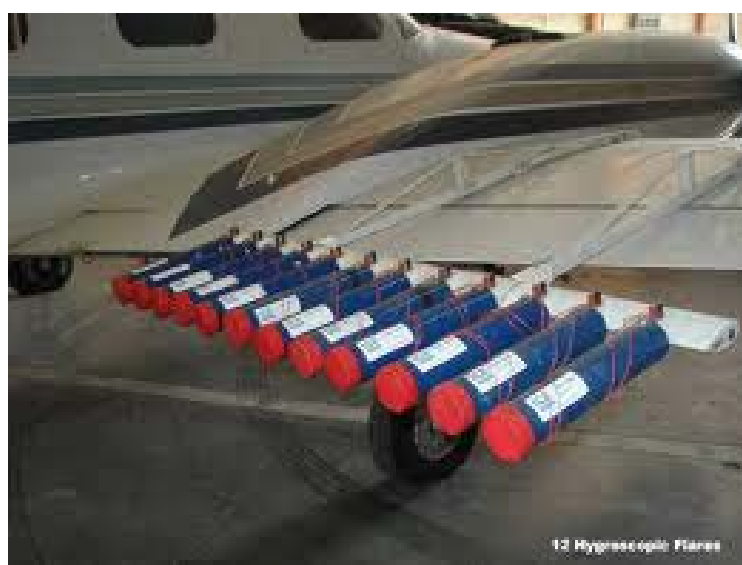

Gambar 4. Flare pada sayap pesawat

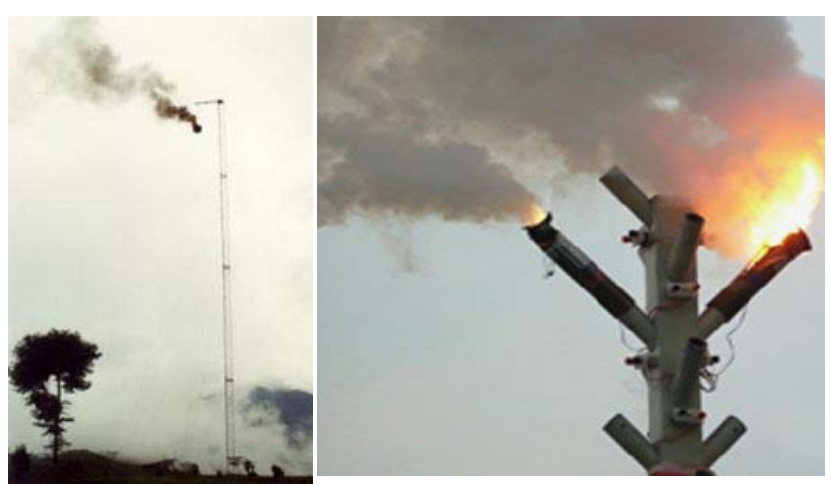

(a)

(b) 


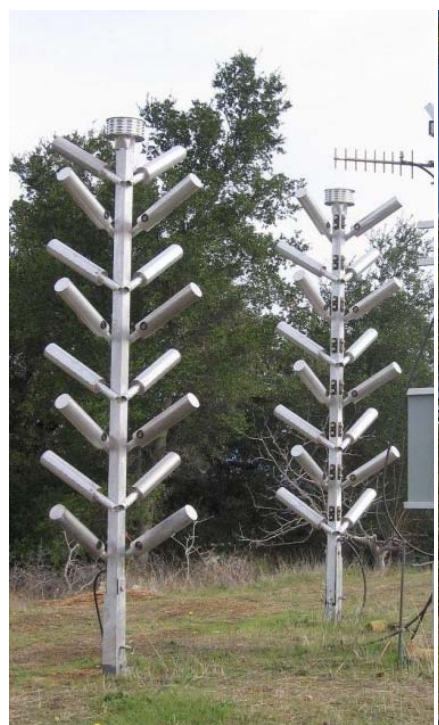

(c)

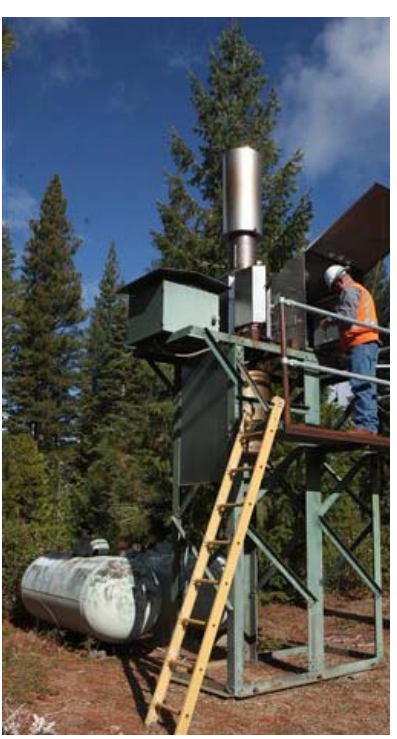

(d)
Gambar 5. Ground Base Generator (GBG) (a) Menara GBG dengan bahan semai flare (b) Proses pembakaran flare pada Pohon Flare (c) Pohon flare berbasis remote control (d) GBG tipe bakar

\section{METODE PENELITIAN}

Dalam tulisan ini dijelaskan konsep baru teknologi modifikasi cuaca dengan media GBG berbasis Wireless Sensor Network (WSN) untuk beberapa waduk PLTA di Indonesia. Dari kajian teori menunjukkan bahwa pembentukan awan orografik terjadi karena adanya lereng gunung yang memaksa massa udara bergerak naik ke atas hingga mencapai level kondensasi. Sehingga dalam karya tulis ini, faktor topografi disebut sebagai penentu kelayakan penerapan GBG untuk operasi TMC disuatu wilayah.

Dalam karya ini dipilih 4 Daerah aliran sungai (DAS) yaitu Singkarak, Koto Panjang, Riamkanan dan Larona sebagai contoh area yang dapat diterapkan GBG. Data DAS yang digunakan tersebut mengacu pada batas DAS yang digunakan oleh UPT Hujan Buatan BPPT saat melakukan kegiatan TMC. Sedangkan untuk datadata topografi diperoleh dari Digital Elevation Model (DEM) dan ditampilkan dengan software Global Maper. Ketinggian atau topografi waduk yang berupa gunung berpotensi menumbuhkan awan-awan orografik sehingga dapat diterapkan penyemaian dari darat berupa GBG. Selanjutnya akan dijelaskan model GBG otomatis dan konsep pengoperasian berbasis Wireless Sensor Network (WSN) berupa gambar ilustrasi dan cara kerjanya.

\section{HASIL DAN PEMBAHASAN}

\subsection{Waduk Pembangkit Listrik Tenaga Air (PLTA)}

Waduk PLTA dan Irigasi merupakan pasar potensial pelayanan TMC. Hampir setiap tahun permintaan TMC untuk sektor ini selalu ada dan meningkat dari tahun-tahun sebelumnya. Karena keterbatasan wahana pesawat, yang saat ini menjadi wahana utama dalam kegiatan TMC di Indonesia, maka tidak semua permintaan dapat terlayani. Melihat kondisi sebagian besar wadukwaduk PLTA di Indonesia dikelilingi oleh pegunungan dan bukit, pengembangan GBG kearah otomatis menjadi solusi untuk menggantikan wahana pesawat. Berikut akan dijelaskan topografi das Riamkanan, Koto Panjang, Singkarak, dan das Larona yang dikelilingi oleh bukit.

\subsubsection{Das Riam Kanan}

Das Riam Kanan terletak di Provinsi Kalimantan Selatan. Danau ini merupakan danau buatan yang dirancang oleh Ir. P.M. Noor untuk memenuhi kebutuhan listrik di Kalimantan Selatan dan Kalimantan Tengah. Citra topografi das Riam Kanan di tunjukkan oleh gambar 7. Dari citra topografi data DEM menunjukkan bahwa danau buatan tersebut dikelilingi oleh gunung. Puncakpuncak bungkit yang dengan ketinggian 700-1200 meter membentang dari barat daya hingga timur laut mengelilingi danau tersebut.

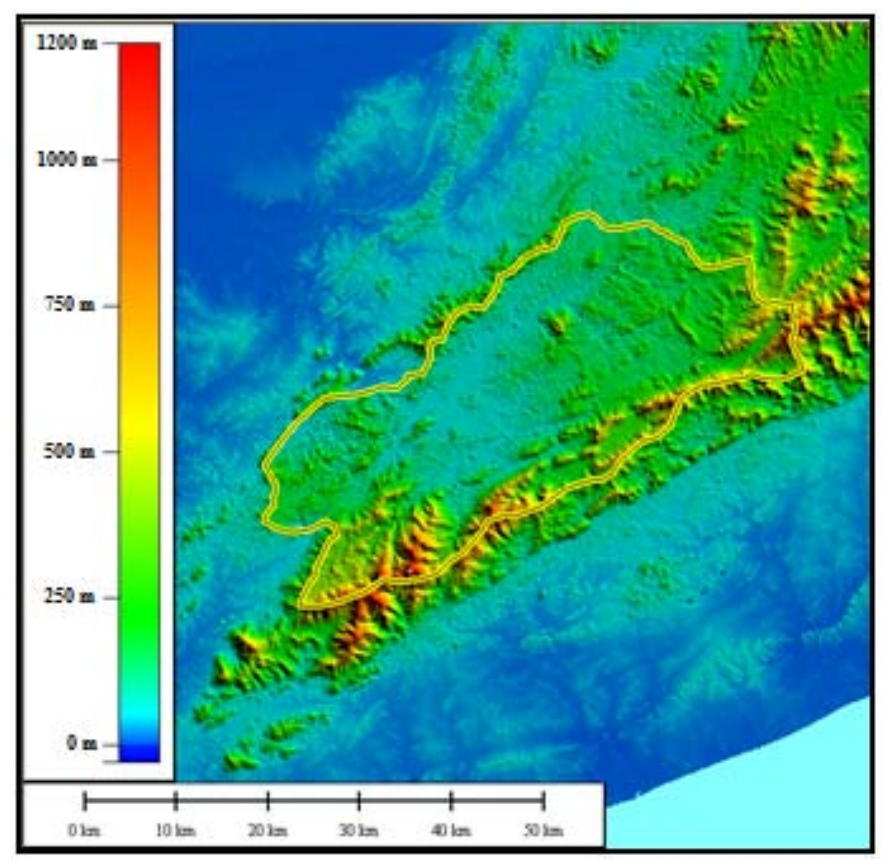

Gambar 6. Topografi DAS Riam Kanan

\subsubsection{Das Larona}

Das Larona merupakan das yang terletak di Sulawesi Tengah. Das ini terdiri dari 3 waduk yaitu Matano, Larona, dan Towuti. Das ini dikelola oleh perusahaan nikel untuk mensuplai kebutuhan listrik di perusahaan tersebut. Danau ini dikelilingi oleh pegunungan dengan tinggi puncak sekitar 1500 meter. Tinggi permukaan danau air danau mencapai 500 meter. 


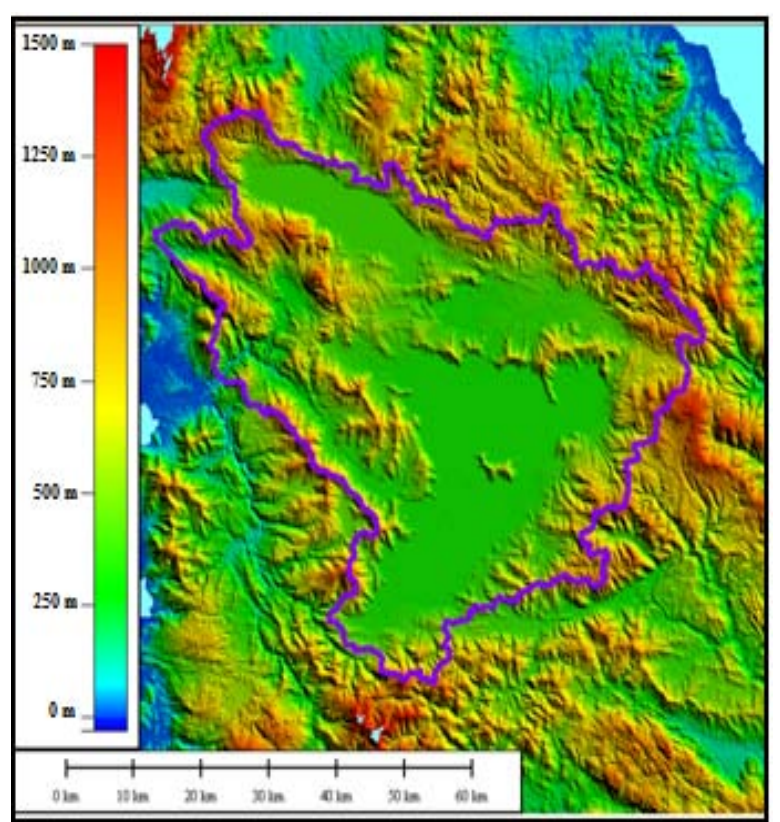

Gambar 7. Topografi DAS Larona

\subsubsection{Singkarak}

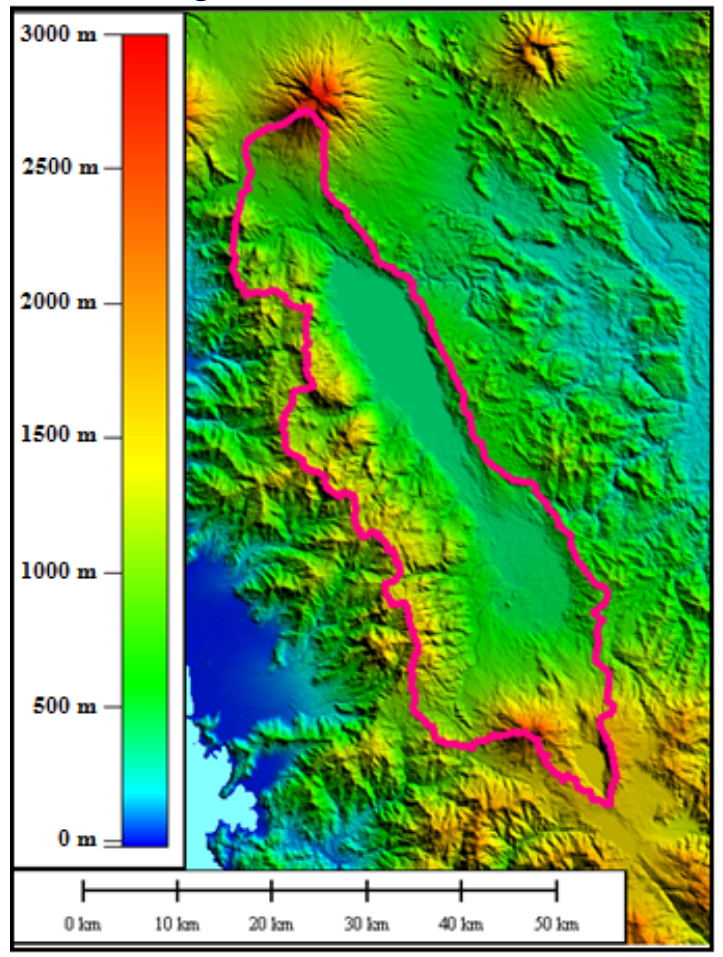

Gambar 8. Topografi DAS Singkarak

Waduk PLTA Singkarak berada di Bukit Barisan Sumatera Barat. Di bagian barat waduk ini dibatasi oleh pegunungan yang cukup tinggi dengan puncaknya hingga mencapai sekitar 1500 feet, sedangkan di bagian selatan dibatasi oleh gunung Talang dan di utara di batasi gunung Singgalang dan Marapi dengan puncak 3000 meter. Sedangkan dibagian tibur dibatasi oleh pegunungan yang lebih pedek dengan ketinggian kurang lebih 500 meter. Ketinggian permukaan danau juga cukup tinggi yaitu sekitar 300 meter.

\subsubsection{Koto Panjang}

Das Kotopanjang terletak di Kabutpaten Rokan Hulu, Provinsi Riau. Das ini Berada di sebelah timur bukit barisan. Sehingga Bagian barat dari Das ini merupakan pegunungan Bukit Barisan dengan ketinggian hingga 2000 meter. Dengan adanya pegunungan cukup tinggi di bagian barat das tersebut, maka awan-awan orografik sering muncul di bagian barat das tersebut yang memungkinkan diterapkanya sistem TMC dengan media GBG.

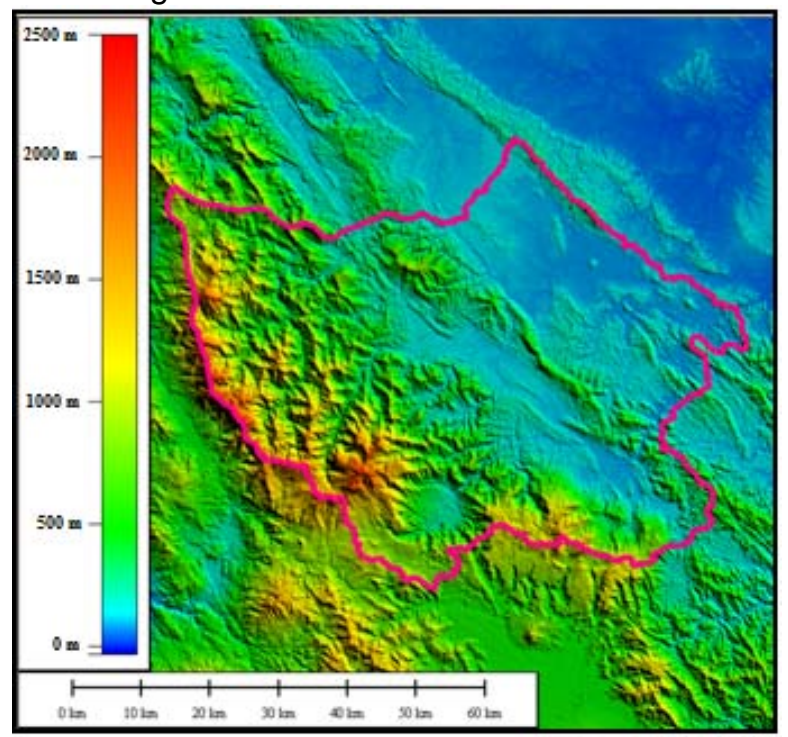

Gambar 9. Topografi DAS Riam Kanan

\subsection{Rancangan dan Konsep Operasional GBG Otomatis}

GBG yang sudah dikembangkan UPTHujan Buatan BPPT saat ini masih dioperasikan secara manual sehingga kurang efektif jika diterapkan dilereng atau bukit yang terpencil dan jauh dari pemukiman. Selain itu, pengoperasian GBG secara manual di daerah terpencil dan jauh dari pemukiman juga akan membahayakan operator GBG. Sehingga dalam makalah ini akan disampaikan ide pengembangan GBG secara otomatis berbasis wireless network yang mampu beroperasi di daerah yang terpencil dan jauh dari pemukiman. GBG yang dikembangkan dapat beroperasi secara otomatis dengan perintah eksekusi penyemaian secara nirkabel. Dengan kemampuan tersebut, penyemaian awan dapat dilakukan kapan saja baik siang hari maupun malam hari. Selain itu, GBG yang dikembangkan juga memiliki fitur penyimpanan bahan semai flare sehingga pengisian flare dapat dilakukan secara berkala. Ilustrasi rancangan GBG otomatis ditunjukkan oleh gambar 8.

Dengan adanya GBG otomatis faktor biaya gaji dan upah dapat dikurangi. Selain itu GBG otomatis yang dapat dikatakan sebagai sebuah robot sederhana akan lebih konsisten dalam melaksanakan eksekusi penyemaian awan, 
dimana alat ini tidak mengenal lelah serta kondisi cuaca.

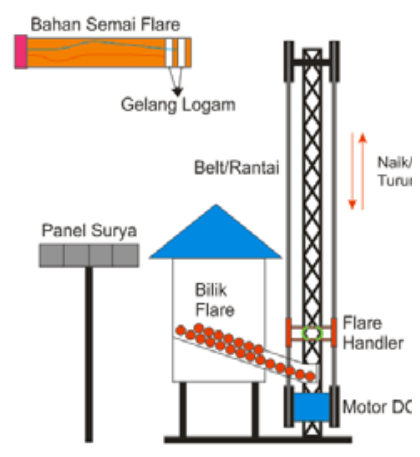

(a)

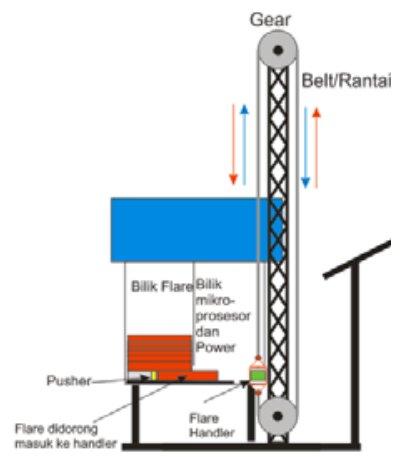

(b)
Gambar 10. Rancangan GBG otomatis (a) tampak depan (b) tampak samping

\subsection{Konsep Pengoperasian GBG berbasis Wireless Sensor Network}

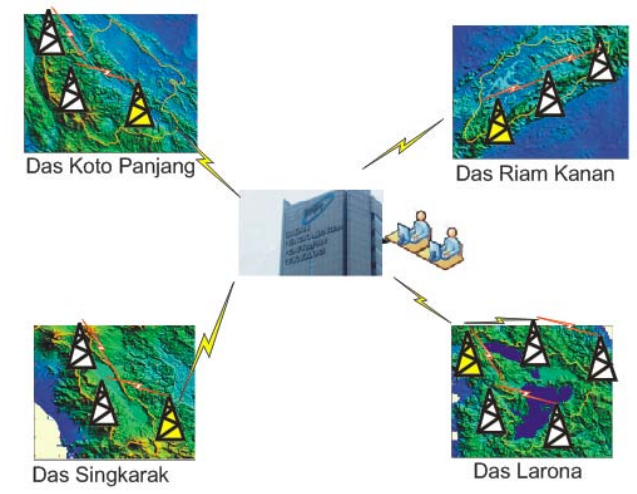

Gambar 11. Ilustrasi topologi Wireless Sensor Network

Pengoperasian GBG dengan

menggunakan wireless sensor network (WSN) merupakan sebuah konsep untuk mengoperasikan beberapa GBG otomatis dengan perintah nirkabel. Selain itu juga di setiap GBG juga dipasang Automatic Weather Station (AWS) dan Radar Cuaca untuk mendeteksi kondisi cuaca dan keberadaan awan potensial diwilayah GBG tersebut ditempatkan. Dengan konsep wireless sensor network (WSN) maka parameter-paramter cuaca dan keberadaan awan potensial dapat dikirim ke server sebagai pusat kendali. Selanjutnya parameter-parameter cuaca ini dapat dianalisis oleh tim yang sedang bertugas dan selanjutnya dapat dilakukan penyemaian awan dengan GBG otomatis dengan perintah melalui komputer server. Konsep pengoperasian GBG berbasis WSN di ilustrasikan dalam gambar 9 .

Dengan adanya GBG otomatis maka waduk PLTA dan irigasi yang memiliki DAS berupa bukit dapat dilayani secara bersama-sama dengan menerapakan wireless sensor network (WSN) .

\section{KESIMPULAN}

Ground-Based Generator (GBG) dapat diterapkan sebagai wahana penyemaian awan untuk pengisian beberapa waduk PLTA di Indonesia yang dikelilingi oleh pegunungan. Data topografi waduk PLTA Riamkanan, Singkarak, Koto Panjang, dan Larona menunjukkan das-das tersebut layak untuk diterapkan TMC dengan wahana GBG. Dengan adanya pengembangan GBG kearah otomatis dan berbasis WSN, maka kegiatan TMC dapat dilakukan secara bersamaan yang berdapak pada pengurangan biaya TMC. Selain itu, keberhasilan dari konsep ini akan menggantikan wahana pesawat dalam operasi TMC yang merupakan faktor pembiayaan terbesar dalam operasi TMC saat ini sehingga air hasil TMC akan semakin ekonomis.

\section{UCAPAN TERIMAKASIH}

Penulis mengucapkan terimaksih kepada M Bayu Rizki yang telah membantu dan memberikan data DEM dan mengajarkan software Global Mapper. Selain itu, penulis juga mengucapkan terimakasih kepada semua pihak yang telah membantu penulisan karya ilmiah

\section{DAFTAR PUSTAKA}

Bayong, T.H.K, 1999. Klimatologi. Institut Teknologi Bandung. Bandung.

Bayong, T.H.K, 1988. Proses Mikrofisis Dan Modifikasi Awan. Seminar Hujan Buatan, Badan Meteorologi dan Geofisika. Jakarta.

Handoko, 1995. Klimatologi Dasar. Pustaka Jaya. Jakarta

Mulyana, 2012. Variasi Diurnal Angin Permukaan di Lereng Gunung Gede Pangrango. Jurnal Sains dan Teknologi Modifikasi Cuaca. Jakarta.

Tim UPT Hujan Buatan, 2014. Peranan Teknologi Modifikasi Cuaca di Indonesia. BPPT Press. Jakarta

Tim UPT Hujan Buatan, 2014. Efektivitas Teknologi Modifikasi Cuaca untuk Mitigasi Banjir (Arti Penting Pengurangan Curah Hujan 30\% Bagi Banjir Jakarta). BPPT Press. JakartaHandoko, 1995. Klimatologi Dasar. Pustaka Jaya. Jakarta

Untung, H, DKK. 2011. The Development of Hygroscopic Cloud Seeding Flare In Indonesia: Evaluation and Measurement of Distribution Particles. WMO conference. Bali. 